\title{
A kínai diaszpórapolitika
}

\section{China's Diaspora Policies}

\section{ÖsszeFoglalás}

A Kínai Népköztársaság határon túli kínaiakra irányuló politikája összetett, sokrétú intézményrendszerrel támogatott, s mára egyre inkább a gazdasági összetevôket szem eloott tartó rendszer. A kivándorlást évszázadokon keresztül egyöntetúen tiltotta minden különbözó államalakulat, míg végül Kína 1978at követôen a tiltás, elzárkózás helyett egyre inkább a diaszpóra integrálása felé fordult, s az azóta eltelt négy évtizedben egy kulturális-gazdasági közösség vagy hálózat létrejöttét, megerôsítését igyekszik támogatni. Erre irányuló elemeket tartalmaznak mind az általános, mind bizonyos szakpolitikák, köztük a határátlépésre vonatkozó szabályozás, a vízum- és vámpolitikák, valamint számtalan határon belüli és kívüli soft power eszköztár, beleértve többek között a nyelvtanítást, a nem kormányzati intézményeket, a kulturális és sajtótermékeket. Kiemelt jelentôségú a diaszpóratagok megszólításának gazdasági eszköztára, a törvényi feltételek könnyítésétôl a tehetségprogramokig. Mindezen különbözô területek tevékenységét és irányítását egyre inkább jellemzi az összehangoltság, egy olyan történeti geopolitikai szemlélet jegyében, mely mára részben szorosabb nagytérségi integrációt céloz, részben azon- ban túlmutat a regionális viszonyrendszeren is, és globális szintre emelkedett.

Journal of Economic Literature (JEL) kódok: F22, F38, J15, J61, K37, O24, Z10

Kulcsszavak: kínai diaszpóra, diaszpórapolitika, sinocentrizmus, gazdaságpolitika

\section{SUMMARY}

The policies of the Public Republic of China, related to the overseas Chinese, is a complex system, which is increasingly concerned with the economic aspects nowadays and is supported by a multifaceted institutional arrangement. Emigration was unanimously banned bay all different state formations through centuries, until finally, after 1978 China gradually turned from ban/ refusal to the integration of the diaspora. During the following four decades China increasingly supported the formation and strengthening of a mostly cultural-economic community or network. Both general and specific policies contain elements with this purpose, including the regulation of border crossing, visa and customs policies and several soft power tools within and outside of the country, such as language teaching, nongovernmental organizations, cultural

Dr. Koudela PÁl PhD, vezetô kutató, Harsányi János Tudásközpont (pkoudela@yahoo.com). 


\section{Tudományos múhely}

and press products and many other fields. Economic means to approach Chinese overseas are of particular importance, from mitigating legal conditions to talent programs. The activities and direction of these different fields are increasingly characterized by alignment in the spirit of a historical geopolitical approach, which targets partly a tighter regional integration but partly goes beyond to a global level.

Journal of Economic Literature (JEL) codes: F22, F38, J15, J61, K37, O24, Z10

Keywords: Chinese diaspora, diaspora policies, sinocentrism, economic policy

\section{Bevezetés}

Jelen tanulmány a migrációs politika egy sajátos szegmensével foglalkozik, s bár annak kapcsolata a gazdasággal és a ki- és bevándorlással sokrétú, megkerülhetetlen külön jelenségként is beszélni róla. Ha ugyanis eltekintünk azon specifikus következményektôl, mint pl. az utóbbi években a tókekivitel serkentése, akkor a Kínai Népköztársaság migrációs politikája meglehetôsen konzervatív. Ez elốbbi is csupán annak köszönhetô, hogy a népköztársaság hatalmas devizatartalékokat halmozott fel, ami felértékelte a renminbit, a kínai devizát. A Nyitott Kapuk Politikája és a tôkebeáramlás segítése, de még a WTO-hoz való csatlakozás is hozzájárult a mai gazdaságpolitika kialakulásához (Davies, 2013), mindez azonban élesen elválik magától a migrációs politikától.

Kína hagyományosan nem támogatta polgárai elvándorlását az ország területérôl. Már a Ming-dinasztia idején léteztek törvények, melyek a kereskedelem korlátozásához köthetôen kiterjedtek a kivándorlás egészére, noha ezek akkor még elsôsorban a technológiát, innovációkat védték. A Csing-dinasztia azonban fokozatosan minden kapcsolódó tevékenységet betiltott. A 19. században, az ópiumháborúk után a Nyugat kikényszerítette a munkaerô-kivitel engedélyezését, mely a nyugati országok számára elengedhetetlenül szükséges forrásnak bizonyult a rabszolga-kereskedelem megszúnése után, s a nankingi szerzôdés tartalmazott is egy passzust errôl, ám törvényi formát csak 1893-ban öltött (Wang, 2000:46). A rá következô évtizedekben tömegessé vált a kivándorlás, amely elsôsorban Délkelet-Ázsiába irányult; ezen idôszakban mintegy kétmillió főre becsülhetô a kínai kivándorlók száma. A folyamat következményeként 1909-ben életbe lépett az elsố modern kori állampolgársági törvény, amely a jus sanguinis alapelvét követve, minden kínai származásút a birodalomhoz tartozónak tekintett, függetlenül attól, hol született, vagy hol él (Bolt, 2000:38). Ezt a nacionalista politikát örökölte késôbb a Kínai Népköztársaság.

A törvény ugyanakkor azon tényezók közé is tartozott, amelyek az elmúlt évszázadban gátolták a kínai kisebbségek integrációját a befogadóországokban. Az állandó „átmenetiség” érzése ugyanis önmagában is elég volt a kínai kultúra - elsôsorban a nyelv - fennmaradásához, az ahhoz szükséges iskolák alapításához; a nagymértékú kivándorlás pedig a szegregáció folyamatos fennmaradását segítette, s a kettô egymásra hatva azt eredményezte, hogy ezen országok szinte idegen testként órizték meg a kínai kisebbségeket.

A huszadik század tehát már komoly lépéseket követelt a kivándorlás szabályozásában és a kint élôk reintegrációjára vonatkozóan is. A Kuomintang 1929-ben hasonló, vérségi alapú állampolgársági törvényt fogadott el, egyúttal létrehozta a Határon Túli Kínai Ügyek Bizottságát; tette mindezt azért, mert a nemzetközi kapcsolatok fejlesztésének eszközeként értelmezte az emigráns közösséget (Fitzgerald, 1972:11). Mindezek hátterében már akkor is a gazdaság állt, alapok létrehozását kezdeményezték, törvény született a hazai befektetések serkentésérôl, és komolyan támogatták az emigráns közösségek kultúrájának megórzését. E tevékenység a két világháború között oda vezetett, hogy a befogadóországok egyre inkább idegenkedve 
néztek a kínai kisebbségekre. A második világháború utáni kommunista fordulat mindezt azzal tetézte, hogy a nacionalizmusukban virágzó délkelet-ázsiai országok kormányai sokszor már kifejezetten felforgató, de legalábbis gyanús személyeket kezdtek látni az ott élô kínaiakban. Az 1949-ben létrejött Kínai Népköztársaság pedig csak nehezen tudta kialakítani a korábbiakkal szöges ellentétben álló nemzetközi kapcsolatrendszerét, különösen éppen a kivándorlóit legnagyobb számban befogadó, nem kommunista országokkal (Bolt, 2000:40-43).

A maoista Kína hol kül-, hol belpolitikájának rendelte alá az emigránskérdést, s annak alakulása szerint változtatgatta hozzáállását. A kulturális forradalom alatt a diaszpóra és a hazatérô kínaiak is burzsoá, kapitalista elemeknek számítottak, így elvesztették jogukat minden korábbi kiváltságukra. 1977-ben azonban fordulat következett be, rehabilitálták a korábbi disszidenseket, és újra életre hívták a Határon Túli Kínai Ügyek Bizottságát is (Chang, 1980:282). A pozitív gazdasági szemlélet az 1990-es években kiegészült az addigra már jelentôs számban külföldre vándorolt diáksággal. A nyolcvanas évek elején megteremtett lehetôség a tudósok és diákok külföldre utazására ugyanis nagyszámú kivándorlót eredményezett fôként Észak-Amerikába, Ausztráliába, Japánba és Európába. A huszadik század végére a népköztársaság ezt jelentôs humán tôkeként azonosította, a gazdaság számára elônyösnek ítélte hazacsábításukat (Thunø, 2001).

\section{A DIASZPÓRAPOLITIKA} INTÉZMÉNYRENDSZERÉNEK KIALAKULÁSA A KILENCVENES ÉVEKBEN

Korábban, tulajdonképpen egészen 1990-ig, csupán egyetlen jogszabály vonatkozott mind a határon túli, mind a hazatelepült kínaiakra: a hazautalások védelméról szóló, 1955-ös határozat. A jogszabály a hazautalásokat jogos személyi bevételnek tekintette, s megvédte minden állami beavatkozástól még akkor is, ha csupán temetések vagy esküvôk költségeit fedezte. Ugyancsak támogatta a külföldön éló kínaiakat a felsôoktatásba való bejutásban, s a politikai tagságuk is külön kvóta szerint múködött. A fordulat 1990-ben következett be, az akkor megalkotott, majd 2000-ben módosított, a külföldrôl hazatérô, illetve a külföldön élők rokonainak védelmérôl és érdekeirôl szóló törvény révén (National People's Congress, 2000), ekkortól ugyanis nem volt garantált, hogy a hazautalásokat a rokonok jólétének növelésére fordítják majd. Ebben az évtizedben már megengedett volt a jövedelemkülönbség a kínai társadalom minden szintjén, s az egyetlen kedvezmény, amely továbbra is megmaradt a hazatelepülók számára, a felsôoktatásba való bejutásuk segítése volt. Ezt követôen kevés tényleges elem támogatta a diaszpóra és az állam kapcsolatát, legfeljebb olyan érzelmi kötődésre apelláló, ám funkcionálisan üres intézkedések, mint a kivándorlókörzetek regisztrációjának fenntartása. Ennek azonban a valós demográfiai alapja már generációk óta tovaszállt, ugyanis a nyitás politikáját követôen a legtöbben elhagyták ezeket a területeket, hogy családjukat egyesítsék - leginkább Hongkongba mentek, a délkelet-ázsiai országok ekkor már nem látták szívesen a kínai bevándorlókat -, így rokoni kötelékek mára nemigen maradtak fenn (Hoe, 2013:143-144).

Az ún. Csiaohsziang területek (jelentése nagyjából: a kivándorlók területe) egy nem hivatalos elnevezés, a név 1949 elôtt ragadt ezekre a területekre a köznyelvben, s vált használatossá a hazai és nemzetközi szakirodalomban is a Csing, majd a köztársasági idôkben, amikor a nagyarányú kivándorlás megindult (Pan, 1998:27-30). Késóbb, 1978 után mind a Határon Túli Kínai Ügyek Bizottsága, mind a Hazatért Határon Túli Kínaiak Hivatala már hivatalosan is használni kezdte a megnevezést. Bármennyire is úgy tûnt, a hazafias érzelmek feltámasztásának kiváló eszközét lelték meg, a délkelet-ázsiai országokban élố kínaiak többsége már nem volt kínai állampolgár, az óket befogadó állam integráns tagjává vált, így alapvetôen kétkedve fogadta egy ilyen eszköz legitimi- 


\section{Tudományos múhely}

tását. Ráadásul mindez ellentmondott Kína azon egyértelmú politikai irányelvének, mely a hongkongi, a Makaón vagy Tajvanon élô kínaiakat nem is tekintette emigránsoknak (nem is tehette, ha azon területeket Nagy-Kína részeként kezelte).

Az évszázadnyi erôsödô kivándorlást követôen tehát - mialatt kínaiak százezrei kerestek jobb megélhetést és menedéket a nyomor és káosz elől, s miután a 19. század közepétôl már nem számítottak árulónak a mindenkori kormányok szemében - az 1949-es év erôs visszaesést mutatott. A maoista Kína nem engedélyezte a korábban virágzó kapcsolatokat a külföldi rokonokkal, sốt megbélyegezte az elvándorlókat. Ebben az idôszakban kettészakadt a hongkongi és a délkelet-ázsiai kapcsolatrendszer: míg az elóbbi továbbra is kivándorlási célpont maradt, sốt a gazdasági kapcsolatok is fennmaradtak az anyaországgal, addig utóbbiban a leszármazottak már inkább saját, helyi kapcsolathálójukat erősítették (Lui, 2000:257-285). 1978-at követôen pedig a kivándorlás inkább az északabbra fekvô Csöcsiang tartományt érintette, elsôsorban a kivándorló diákok révén, így Délkelet-Kína megosztottá vált, gazdaságilag és demográfiailag egyaránt. A Hongkonghoz közel esố területek prosperáltak, a kevés támogatást élvezô belsố és hegyvidéki területek hanyatlani kezdtek (Hoe, 2007:88-89).

A kilencvenes években a kormány a határon túl élőkkel kapcsolatban már nem reménykedett abban, hogy a kapcsolatok fokozásával nagyobb mértékben tudja a hazautalások vagy a befektetések mértékét fokozni, inkább abban, hogy ezzel lehetôséget teremt egy olyan virtuális kínai nemzetközi közösség létrehozására, amely hosszú távon hozzájárulhat a Tajvannal való egyesüléshez (Thunø, 2001:922). Ennek érdekében különbözô kormányszervek alakultak. A Kínai Népi Politikai Tanácskozó Testület - mely idôsebb szerv a népköztársaságnál - által eredetileg 1949-ben létrehozott és 1978-ban megújult Határon Túli Kínai Ügyek Bizottsága továbbra is fennmaradt, és a mai napig a fó kapcsolattartó a diaszpórával, kutatáso- kat szervez, felméréseket végez (Overseas Chinese Affairs Office, 2009). Munkáját 1992-ben újabb intézmény kezdte segíteni: az Államtanács Határon Túliak Hivatalának keretei közt jött létre a Kínai Határon Túliak Csereforgalmi Egyesülete, melynek fố célja egyfajta tömegméretú NGO-ként funkcionálni, baráti kapcsolatok keretein belül az együttmúködést segíteni. A diaszpóra számára lassan kényelmetlenné vált a népköztársaság továbbra is alkalmazott szemlélete, amely huacsiaóként, vagyis határon túli kínaiként értelmezte ôket. Ez a már máshová integrálódott, külföldi s nem kínai állampolgárok számára ellentmondásos és kényelmetlen helyzetet teremtett (ChengNgok, 1999:117). A szervezet céljai között tehát ennek a feszültségnek az enyhítése is szerepelt, de létrejöttek tartományi intézmények is hasonló céllal. 1997-ben megalakult a Kínai Határon Túliak Baráti Társasága, melynek célja Kína fiainak és lányainak s az anyaföld egységének támogatása lett.

Ezek a többé-kevésbé állami szervek kiterjedt propagandát folytattak a diaszpórával való kapcsolatok élénkítése érdekében. Eszközeik a média és az internet fejlődésével egyre kiterjedtebbé váltak, de fố karakterét, az írott formát mindvégig megórizte. A még a nyolcvanas években újraindított sajtót, hírleveleket egyre szélesebb körben kezdték terjeszteni külföldön is, 1998-ra már kétmilliós összpéldányszámot érve el (Thunø, 2001:924). A kínai kultúra és oktatás támogatása külföldön is az egyik fố feladattá vált: az ezredfordulóra 78 országban alapítottak kínai iskolát húsz különféle tanmenettel, százötven kínai tanár utazott külföldre, és több ezer határon túli kínai tanárt hívtak haza továbbképzésre. Nyári táborok, nemzetiségi és gazdasági szervezetek jöttek létre, melyek mind egy tudatos Nagy-Kína-koncepció részeként igyekeztek integrálni a diaszpórát a kínai nemzet kebelébe (Hong, 1999:87-113).

A kilencvenes évek második felében több tényezó is közrejátszott abban, hogy Kína tovább folytatta soft power stratégiáját a határon túli közösségek és az anyaország 


\section{Tudományos múhely}

integrációjának erôsítésére. A harmadik Tajvani-szoros-krízis 1995-1996-ban megmutatta, hogy Kína keményebb eszközökkel nem érheti el a céljait Tajvannal kapcsolatban, az 1997-es ázsiai gazdasági válság pedig valójában kedvezett annak, hogy a délkelet-ázsiai országokban éló kínaiak erôsítsék pozíciójukat, és fokozzák a helyi politikában való részvételüket. A kilencvenes évek általánosságban is sok változást hoztak Kína kül- és belpolitikájában: sorra születtek a bilaterális egyezmények, melyekkel a korábbi területi vitáit rendezte, sokszor messze elmaradva a kitúzött céltól (pl. a Tádzsikisztánnal szembeni területi igényéből a Pamír hegységben 28 ezer négyzetkilométer helyett csupán egy jutott).

A pártvezetés is jelentôsen megváltozott: a kilencvenes évek végére, a tizenötödik nemzeti kongresszusra a harmadik és negyedik generációból álló, huszonnégy vezetô átlagos életkora egy évtizeddel csökkent, mint volt a tizenkettedik kongresszus idején, 1982-ben. Persze azért még így is hatvanhárom év maradt az átlagéletkor (Miller-Liu, 2001:127), de nagy részük, tizenheten a huszonnégyből már egyetemet végzett, míg 1982-ben még a tagok egyike sem rendelkezett felsôfokú végzettséggel. Ráadásul sokan közülük külföldön végezték a tanulmányaikat, s ez vélhetôen hatással volt Kína nemzetközi kapcsolatrendszerben elfoglalt helyére, az ország megítélésére (MedeirosFravel, 2003). Kína már nem az elnyomott, kizsákmányolt nemzet képét mutatta többé, hanem egy erôs nagyhatalomét. Mindehhez hozzájárult az is, hogy az 1997-ben és 1999-ben visszakapott Hongkong és Makaó hatalmas gazdasági és politikai nyereséget hozott Kínának. Mindez nem jelentette azt, hogy alapvetô geopolitikai felfogása megváltozott volna, csupán már nem rakétákkal akarta megoldani a Tajvan-kérdést. Miután a Kínai Köztársaság (Tajvan) modern demokráciává alakult át, s 1996-ban megtartották az elsố közvetlen elnökválasztást, ráadásul 76 százalékos részvétellel (Rinza, 2001:558), a népköztársaság úgy döntött, inkább meg- próbálja izolálni a szigetországot, mintsem meghódítani, s a washingtoni diplomáciai képviselói lobbicégeket béreltek fel, hogy segítsék a kongresszus ez irányú tevékenységét a bilaterális és multinacionális intézményi kapcsolatrendszerében (Chi, 2002:121).

\section{Az EMIGRÁCIÓVAL FOGLALKOZÓ HIVATALOK ESZKÖZTÁRA}

Kína alapvetően három eszközt használ a határon túli kínaiak integrálására: az iskolákat, az újságot és az önkéntes társaságokat, beleértve a kulturális társaságtól az üzleti kamarán át a klánokig (Kuah-Pearce-Hu-Dehart, 2006:14). A Határon Túli Kínai Ügyek Hivatala az alábbiakban határozza meg tevékenységének céljait: a hazai és külföldi kutatás a határon túli kínai kapcsolatok fejlődése és helyzetük ügyében; információgyújtés a KB számára; tervek kidolgozása; jogaik és érdekeik védelme; az egység és barátság fokozása a külföldön élók és a nemzet között; a kínai média és nyelviskolák támogatása külföldön; a határon túliak és Kína közötti kooperáció és cserekapcsolatok erôsítése a gazdaság, tudomány, kultúra és oktatás terén; a hazatérô kínaiak támogatása. Emellett még számos adminisztratív feladatot jelöl meg, a pártfótitkár asszisztenciájától a felelôs minisztériumi szervek közötti közvetítésig (The State Council, 2014).

Az idôk folyamán a nem állami érdekvédelem és szervezeti élet is fejlődésnek indult. Mára az Államtanács Külföldi Kínaiak Hivatala mellett a Kongresszusban múködik a Külföldi Kínaiak Bizottsága (1983 óta), valamint a Kínai Nép Politikai Egyeztetố Konferenciája kötelékében a Hongkong, Makaó és Tajvan Diaszpóra Bizottság. Ezek a tanácsadó testületek tulajdonképpen állami szervezetek, de már 1956-ban létrejött a diaszpóra ügyeinek védelmében a Hazatért Tengerentúli Kínaiak Összkínai Egyesülete elnevezésú jog- és érdekvédő szervezet, s habár a kulturális forradalom alatt felfüggesztették, 1978 óta újra múködik (Shen, 2012:67). A hazatért kínaiak és családjuk 
számára létrehozott NGO leginkább egyfajta közvetítôszerepet tölt be a Kommunista Párt, a kormány és a hazatért kínaiak között, fesztiválokat szervez, díjakat alapít és ad át kiemelkedố teljesítményt nyújtó volt emigránsoknak. Ennél azonban sokkal régebbre nyúlik vissza a diaszpóra érdekvédelme.

A Triádok összefoglaló névvel illetett búnszervezetek létrejöttét Hongkong NagyBritannia fennhatósága alá kerülésének idejére teszik. Az általánosítás sokszor oly mértékú lehet, hogy minden szervezetet amely sokszor éppen ezen okból kénytelen titkosan múködni - együvé sorol, legyenek azok testvéri szervezetek vagy vallási szekták. Így történt ez a Csing, a Köztársaság és a kommunista Kína idejében is (Ownby, 1995:1023). A Tiandihui, hivatalosan, ismertebb nevén a Menny és Föld Szövetsége 1762-ben jött létre Fucsien tartományban (Murray, 1994:16-17). A hasonló vallási szekták tiltottak voltak a Csing kori Kínában is, s a rá következô évtizedek során sok tagjuknak menekülnie kellett az országból Sziámba, és az Egyesült Államokba. A tagok érthetôen szembekerültek a kínai vezetéssel, a külföldiek támogatták az otthon maradottakat, s mivel egyébként is fontos szerep jutott a szervezetben a Ming-dinasztia iránt lojális vezetôknek, a társaság lassan államellenes politikai jelleget öltött. 1911 után azonban, a Csing-dinasztia bukásával eme célok talajukat vesztették, és mivel sok titkos szervezet létezése okafogyottá vált, a bûnözés felé fordultak, végül így jöttek létre a Triádok.

Van azonban egy különösen fontos eleme is a földalatti mozgalmak történetének. San Franciscóban 1925-ben, a korábban a Csing-dinasztiával szemben Csang Kaj-seket támogató mozgalom két tagja, szabadkómúves támogatással, létrehozta a Kínai Cse Kung Pártot. A párt tagjai hamarosan hazatértek, s elôbb a japán megszállás ellen küzdöttek Mandzsúriában, majd a népköztársaság megalapításában is szerepet játszottak; sốt az elsố kongresszuson is részt vettek. A párt tagsága mára mintegy négymillió fơ, nagyrészt hazatért kivándorlókból áll, s jelentős szerepet játszik Kína külföldi érdekeltségeivel és a diaszpórával való kapcsolattartásban (Zagami, 2016:24-25; Brief Introduction, 2012). Olyan országokkal is összeköttetésben áll, amelyekkel Kína nem tart fenn diplomáciai kapcsolatot, így ezen a párton keresztül mégis érintkezni tud velük, mikor a szükség úgy hozza.

A sajtó a diaszpóra integrációjának egyik legfontosabb eszköze. Az ezredfordulóra negyvenhárom kínai újságot nyomtattak Ausztrália-szerte, s egy huszonnégy órás rádióadó is múködött már a kontinensországban. Japánban negyven különféle médium jelenik meg, Európában a kétezres évek elsố felében harminc különféle kínai újságot adtak ki, a számuk folyamatosan nó (Barabantseva, 2012:127). Magyarországon pedig 2011-ben hat különbözố kínai nyelvú napilapot jelentettek meg (Karácsony, 2011). 2004-ben megalapították a Konfuciusz Intézeteket, melyek szerte a világban múködnek, feladatuk a kínai nyelv és kultúra terjesztése, s habár sok kritika érte óket azért, hogy más, hasonló intézményekkel ellentétben, egyetemek keretein belül létesülnek, s hogy ez a tény a tudományos szabadság rovására mehet, 2014-ben már 465 ilyen intézet folytatott munkát a világ 123 országában (Tiezzi, 2014). Nem újdonság a kínai diaszpórák történetében a hazai klánok mintájára szerveződött titkos társaságok vagy akár virtuális, akár valós rokoni kötelékeken alapuló szervezetek. A „corporate family” mintájára létrejött egyesületek tevékenysége kiterjed az érdekképviselettôl a segélyezésen, hagyományôrzésen, kulturális és vallási élet szervezésén át az erkölcsi normák szigorú és pontos betartatásáig (Nyíri, 1996:120-121). Mára a nacionalista kínai retorika ezeket a hagyományokat is felhasználja a diaszpóra nemzettestbe integrálására, s a határon túli kapcsolatok erôsítésén keresztül saját gazdasági és geopolitikai pozíciójának erősítését célozza meg. Már a kilencvenes évek végéig is száz nemzetközi shetuan találkozó jött létre világszerte; így például 1996-ban a Második Fucsiani Világtalálkozón Langkawi- 


\section{Tudományos múhely}

ban, Malajziában 2500-an vettek részt (Liu, 1998). Ezek a találkozók többnyire igen jól szervezettek: szemináriumok, a helyi kultúráról rendezett nemzetközi konferenciák vagy akár kulináris fesztiválok, néptáncrendezvények is részét képezhetik egy-egy ilyen eseménynek. Mindez tökéletes alkalom a kollektív emlékezet megerôsítésére (Liu, 1999:119-120). Hazánkban 1993 és 2011 között hatvanhárom kínai társadalmi szervezet, shetuan alakult.

\section{A DIASZPÓRAPOLITIKA GAZDASÁGI MEGFONTOLÁSAI}

Kína elsôdleges érdeke a diaszpórával egy gazdasági blokk létrehozásának elôsegítése Ázsiában, mely az EU-hoz hasonló, s melynek ó az irányítója. Ha ez talán túl messzire nyúló vagy túlzottan nagyszabású elképzelés is, a kínai termékeknek piacot teremteni Délkelet-Ázsiában, vagy biztosítani a természeti erőforrásokat mindenképpen rövid távú cél, s az anyaország mindehhez az ott élő kínai közösségekkel való kapcsolatát igyekszik felhasználni.

Egy ilyen, tisztán gazdasági természetû kapcsolatra - amennyiben valóban lehetséges elkülöníteni - álljon itt a következô példa. Chia Eksaw 1921-ben települt át Kínából Bangkokba, s nyitott ott vetómagüzletet. Mire negyedik fia, Dhanin 1964-ben átvette az üzletet, már egyéb mezôgazdasági termékeket is árultak, s az üzlet is jócskán kibóvült. A Chia Eksaw nevú üzlet ekkor már baromfival, tojással és más termékekkel is foglalkozott tehát, s hogy olajozottabbá tegye múködését, thaiföldi hivatalnokokkal kereste a kapcsolatot; de nem felejtette el azt sem, hogy a jó üzlethez folyamatos innovációkra is szükség van. Eltelt néhány évtized, s mára Délkelet-Ázsia legnagyobb agráripari cégévé nôtte ki magát, bangkoki központja igazán impozáns, a falakat szép, kínai hegyeket és folyókat ábrázoló tájképek díszítik. Az ezredfordulóra Dhanin egymaga egymilliárd dollár értékú eszközzel rendelkezett. A cég múködésére jellemzô, hogy már a maoista
Kínával tartott fenn kapcsolatot, és volt az elsố külföldi beruházó Kínában, sốt akkor sem vonta ki a tôkéjét, amikor 1989-ben a Tienanmen téri vérengzést követôen sokan megtették ezt. A kilencvenes évekre ez a cég lett a legnagyobb beruházó a népköztársaságban (Kurlantzick, 2007:74-75).

A kínai diaszpóra másfél trillió dollár fölött rendelkezik, s bár csak három százalékát teszi ki az anyaország népességének, mára a gazdaság nyolcvan százalékát kontrollálja. 2017-ben egy elemzés egyértelmúen kimutatta, hogy a kínai kivándorlóknak jelentôs pozitív tovagyûrúzô hatása van a belföldi kínai cégek termelékenységére és kutatás-fejlesztésére. Ezzel szemben a nem kínai befektetések áthatásai negatívak a termelékenység területén, s a fejlesztésben is jóval kevésbé hatékonyak (Wei et al., 2017).

Mindenesetre a 2004-ben kiegészített, 1982-es Alkotmány 50. cikke kimondja, hogy a Kínai Népköztársaság védi a hazatért külföldi kínaiak és családtagjaik legitim jogait és érdekeit (The National People's Congress, 2004). Az említett 1990-es törvény pedig biztosítja az egyenlő bánásmódot, a különleges védelmet, és tiltja a hátrányos megkülönböztetést. Az alapvetô jogalkotás tehát megteremtette a hátteret ahhoz az elvhez, amit tulajdonképpen már a maoista idóktól, de Teng korától egész biztosan követ a népköztársaság: erôsíteni a diaszpórát, mind a határon túl, mind otthon, segíteni az integrációjukat otthon, s erôsíteni a kapcsolatukat mind a hazai, mind a befogadóországgal (Liu-Du, 2014). 2010-ben a Közbiztonsági Minisztérium enyhített a külföldiek tartózkodásának szabályozásán, ami kifejezetten a diaszpórát célzó változtatás volt, s a 2012-es ki- és belépésigazgatási tv. Q1 és Q2 jelölésú, külön rokonlátogató vízumtípusokat hozott létre (Embassy of the People's, 2013).

Számtalan tehát az eszköz, amellyel a határon túli kínaiakat szándékoznak integrálni, a hazaköltözést igyekeznek elôsegíteni, hiszen a nemzettest részeként kezelik azokat is, akik már régen elszakadtak Kínától. Habár a hazaköltözés és hazautalás kettőse között alapvető 
fordulat állt be a kilencvenes években, nem állítható egyértelmúen, hogy Kína bármelyik szegmensrôl lemondott volna. A tôke és humán tôke hazacsábítása egyaránt meghatározó cél továbbra is. Kína 2012-ben már hatvanöt irodát múködtetett negyven országban, melyek a külföldi diáksággal való kapcsolat fenntartását szolgálták. Az Oktatási Bizottság 1987-ben létrehozott egy, a külföldi diákságnak szóló magazint, s fokozatosan igyekezett elômozdítani a hazatérésüket, mára pedig kormányzati webportálok tucatja próbálja a külföldön élố kínai tudósokat megmozgatni. A bizottság már a kilencvenes években éves találkozókat rendezett Kínában, ahol a kormányhivatalokat és hazai vállalatokat ismerhették meg a külföldi diákok; kutatócsoportokat hozott létre a kérdés tanulmányozására, így 1991-ben a Határon Túli Tanulmányok Összkínai Kutató Szövetségét a Pekingi és a Csinghua Egyetemmel az élén. A hazatérô külföldi kínaiak számára a családjuk könynyebb beilleszkedését is igyekezett elôsegíteni, pl. a kínaiul már alig vagy egyáltalán nem beszélô gyerekek számára nyelviskolákat hoztak létre (Zweig, 2006:196).

Állásajánlatok, kutatói ösztöndíjak, startuphitelek, szolgáltató és üzleti parkok, pénzügyi alapok és infrastruktúra-fejlesztés segítik a hazatérést mind a tôke, mind a humán tôke számára. Kanton 12 ezer dollár "golden helló”-val fogadja a hazatérô, ott dolgozni szándékozót, 2015-ben már 310 ipari park múködött 22 ezer aktív vállalkozással és 63 ezer újonnan hazatért kínaival (Xiang, 2016:15-16). 1994-ben a Kínai Tudományos Akadémia létrehozta a Száz Tehetség Programot, mely 1998-ban indult a külföldi kínaiak számára is, 2001-ben tudományos kutatói programmal kiegészülve majd ezer kiemelkedô szakembert vitt haza Kínába. 2008-ban ezt a programot felváltotta a kormány Ezer Tehetség Programja, amely már professzori és kutatói állásokat kínál a legnevesebb egyetemeken és kutatóintézetekben (Recruitment Program of Global Experts, 2016). A projekt 160 ezer dollárt kínál minden olyan szakértônek, aki
5-10 éve dolgozik valamilyen neves külföldi egyetemen, valamint további kutatási ösztöndíjakat ajánl a Tudományos Akadémia is. Mindez még amerikai mértékkel is magas összeg, ennek ellenére a fiatalok visszatérési aránya meglehetôsen csekély. A 2002ben az Egyesült Államokban fokozatot szerzett tudósok közül 2007-ben 92\% még mindig a tengerentúlon tartózkodott (Sharma, 2013). 2011-ben tehát egy másik programot is meghirdettek Kínában, az Ezer Fiatal Tehetség Program válogatott fiatal tudósok számára ugyancsak kétezer fốt célzott meg, de az elóbbi terv ötvenöt éves korhatára helyett az utóbbi keretei közt negyvenéves kor alattiakat toboroznak (Wei-Sun, 2012).

\section{ÖsSZEFOGLALÁS}

Kínának a 2008-as gazdasági válságot követốen összességében sikerült mind a külföldön tanuló diákok, mind a hazatérô tudósok számát növelni, így a kivándorlás és a diaszpórapolitika eme szegmense tulajdonképpen tudatos gazdasági programmá vált. Ha nem is volt minden erre irányuló kísérlet egyformán sikeres, egyfajta rugalmasság is érzékelhetô, mellyel az állam az eszköztárrendszerét igazítja egyfajta pragmatikus elképzeléshez, a külföldön éló kínaiak gazdasági-szellemi integrációjához. Ezt mutatja magának a fogalomnak az igen tág értelmezése is, melyrôl egy korábbi írásban már beszámoltam (Koudela, 2017).

Mindez alapvetôen eltér a történelmi hagyományoktól, a kivándorlás egyszerú tiltásától és szankcionálásától. Kína diaszpórapolitikája úgy is értelmezhetô, mint egyfajta radikális szemléletváltozás, ha a szabadságjogok és az állam szuverenitása felól nézzük a kérdést. Ugyanakkor érdemes a Mao halála óta tartó fejlódést inkább az évezredes kínai geopolitikai szemlélet szerves részének tekinteni, mintsem alapvetô fordulatnak. Kína, noha keleti irányba sikertelenül, de hagyományosan egyfajta imperialista felfogással gondolt földrajzi környezetére, s ezt mind ideológiában, mind a kialakított kvá- 


\section{Tudományos múhely}

zifeudális függôségi viszonyrendszerben érvényesítette is (Kang, 2010:137). A gyakran sinocentrikus világképnek nevezett szellemi konstrukció pedig jóval az imperialista Kína elôtti világképre nyúlik vissza. Mindezek fényében egy kulturális alapokon nyugvó globális hálózat csupán a tér mennyiségi változását jelenti, s nem annak alapvetố geopolitikai átértelmezését.

\section{FeLHASZnÁLT IRODALOM}

Barabantseva, Elena (2012): Overseas Chinese, Ethnic Minorities and Nationalism. De-Centering China. Asia's Transformations Series, Routledge, London, https://doi.org/10.4324/9780203845462.

Bolt, Paul J. (2000): China and Southeast Asia's Ethnic Chinese. State and Diaspora in Contemporary Asia. Praeger Publishing, Westport.

Brief Introduction (2012) to China Zhi Gong Party. www.zg.org.cn/zgparty/party/ (Letöltés: 2018. április 3.).

Chang, C. Y. (1980): Overseas Chinese in China's Policy. The China Quarterly, Vol. 82, No. 2, 281-303, https://doi.org/10.1017/S0305741000012376.

Cheng, Joseph Y. S. - Ngok, Kinglun (1999): Government Policy in the Reform Era: Interaction Between Organs Responsibel for Overseas Chinese and Quiaoxiang Communities. In: Douw, Leo et al. (eds.): Qiaoxiang Ties. Interdisciplinary Approaches to 'Cultural Capitalism' in South China. Routledge, London, 113-143.

Chi, Tsung (2002): From the China Lobby to the Taiwan Lobby: Movers and Shakers of the USChina-Taiwan Triangular Relationship. In: Koehn, Peter H. et al. (eds.): The Expanding Roles of Chinese Americans in U.S.-China Relations. Transnational Networks and Trans-Pacific Interactions. M.E. Sharpe, Armonk, 108-125.

Davies, Ken (2013): China Investment Policy. An Update. OECD Working Papers on International Investment, 2013/01, OECD Publishing, http:// dx.doi.org/10.1787/5k46911hmvbt-en.

Embassy of the People's Republic of China (2013): About Chinese Visa. Embassy of the People's Republic of China in the United States of America, Washington, www.china-embassy.org/eng/visas/ zyxx/t1071018.htm (Letöltés: 2018. április 3.).

Fitzgerald, Stephen (1972): China and the Overseas Chinese. Cambridge University Press, New York.
Hoe, Yow Cheun (2007): Detraditionalized and Renewed. Qiaoxiang Areas: Case Studies of Panyu and Wenzhou in the Reform Period since 1978. In: Thunø, Mette (ed.): Beyond Chinatown. New Chinese Migration and the Global Expansion of China. NIAS Press, Copenhagen, 83-115.

Hoe, Yow Cheun (2013): Guangdong and Chinese Diaspora. The Changing Landscape of Qiaoxiang. Routledge Contemporary China Series, Routledge, London, https://doi.org/10.4324/9780203081020.

Hong, Liu (1999): Bridges Across the Sea: Chinese Social Organizations in Southeast Asia and the Links with Qiaoxiang, 1900-49. In: Douw, Leo et al. (eds.): Qiaoxiang Ties. Interdisciplinary Approaches to 'Cultural Capitalism' in South China. Routledge, London, 87-113.

Kang, David C. (2010): East Asia Before the West: Five Centuries of Trade and Tribute. Columbia University Press, New York.

Karácsony Szandra (2011): Virágzik a kínai média hazánkban. Kitekintô, március 14., http://kitekinto.hu/eia/2011/03/14/viragzik_a_kinai_ media_hazankban/ (Letöltés: 2018. április 3.).

Koudela Pál (2017): A kínai diaszpóra. Polgári Szemle, 13. évf., 1-3. sz., 370-384, https://doi. org/10.24307/psz.2017.0931.

Kuah-Pearce, Khun Eng - Hu-Dehart, Evelyn (2006): Introduction: The Chinese Diaspora and Voluntary Associations. In: Kuah-Pearce, Khun Eng - Hu-Dehart, Evelyn (eds.): Voluntary Organizations in the Chinese Diaspora. Illusions of Open Space in Hong Kong, Tokyo, and Shanghai. Hong Kong University Press, Hong Kong, 1-29.

Kurlantzick, Joshua (2007): Charm Offensive. How China's Soft Power Is Transforming the World. Yale University Press, New Haven.

Liu, Guofu - Du, Zejun (2014): The People's Republic of China Policy and Institutional Frameworks, National Report. Interact Research Report, 2014/19, European University Institute Robert Schuman Centre for Advanced Studies, Florence.

Liu, Hong (1998): Old Linkages, New Networks: The Globalization of Overseas Chinese Voluntary Associations and Its Implications. The China Quarterly, Vol. 155, No. 3, 583-609, https://doi. org/10.1017/s0305741000050001.

Liu, Hong (1999): Globalization, Institutionalization and the Social Foundation of Chinese Business Networks. In: Yeung, Henry Wai-chung - Olds, Kris (eds): The Globalisation of Chinese Bu- 


\section{Tudományos múhely}

siness Firms. Palgrave Macmillan, London, 105125, https://doi.org/10.1057/9780230599925.

Lui, Ping-Keung (2000): Hong Kong Special Administrative Region: Waves of Chinese Immigrants and Their Children. In: Peng, Xizhe - Guo, Zhigang (eds): The Changing Population of China. Blackwell Publishers, Oxford, 257-285.

Medeiros, Evan S. - Fravel, M. Taylor (2003): China's New Diplomacy. Foreign Affairs, Vol. 82, No. 6, 22-35, https://doi.org/10.2307/20033754.

Miller, H. Lyman - Liu, Xiaohong (2001): The Foreign Policy Outlook of China's ,Third Generation" Elite. In: Lampton, David M. (ed.): The Making of Chinese Foreign and Security Policy in the Era of Reform, 1978-2000. Stanford University Press, Stanford, 123-150.

Murray, Dian H. (1994): The Origins of the Tiandihui. The Chinese Triads in Legend and History. Stanford University Press, Stanford.

National People's Congress (2000): Law of the People's Republic of China on the Protection of the Rights and Interests of Returned Overseas Chinese and the Family Members of Overseas Chinese. National People's Congress, www.npc.gov.cn/englishnpc/Law/2007-12/12/content_1383902.htm (Letöltés: 2018. április 3.).

Nyíri Pál (1996): Egyén és közösség: kínai társadalmi szervezetek Magyarországon, 1989-1995. In: Sik Endre - Tóth Judit (szerk.): Táborlakók, diaszpórák, politikák. MTA Politikai Tudományok Intézete, Budapest, 119-129.

Overseas Chinese Affairs Office (2009) of the State Council. www.gov.cn/english//2005-10/03/ content_74290.htm (Letöltés: 2018. április 3.).

Ownby, David (1995): The Heaven and Earth Society as Popular Religion. The Journal of Asian Studies, Vol. 54, No. 4, 1023-1046, https://doi. org/10.2307/2059958.

Pan, Lynn (1998): The Encyclopedia of the Chinese Overseas. Archipelago Press \& Landmark Books, Singapore.

Recruitment Program of Global Experts (2016) The Thousand Talents Plan. www.1000plan.org/ en/plan.html (Letöltés: 2018. április 3.)

Rinza, Marianne (2001): Taiwan (Republic of China). In: Nohlen, Dieter et al. (eds.): Elections in Asia and the Pacific. A Data Handbook: Volume II: South East Asia, East Asia, and the South Pacific. Oxford University Press, Oxford, 525-570, https:// doi.org/10.1093/0199249598.003.0016.
Sharma, Yojana (2013): ‘Thousand Talents' Academic Return Scheme under Review. Universitiy World News, 25 May, No. 273, www.universityworldnews. com/article.php?story=20130524153852829 (Letöltés: 2018. április 3.).

Shen, Huifen (2012): China's Left-Behind Wives, Families of Migrants from Fujian to Southeast Asia, 1930s1950s. Hong Kong University Press, Singapore.

The National People's Congress of the People's Republic of China (2004): Constitution of the People's Republic of China. Chapter II: The Fundamental Rights and Duties of Citizens, Article 50, www.npc.gov.cn/englishnpc/Constitution/ node_2825.htm.

The State Council of the People's Republic of China (2014): Overseas Chinese Affairs Office of the State Council. http://english.gov.cn/state_council/2014/10/01/content_281474991090995.htm.

Thunø, Mette (2001): Reaching Out and Incorporating Chinese Overseas: The Trans-territorial Scope of the PRC by the End of the 20th Century. The China Quarterly, Vol. 168, No. 4, 910-929, https://doi.org/10.1017/s0009443901000535.

Tiezzi, Shannon (2014): The Future of China's Confucius Institutes. The Diplomat, September 30, http:/ / thediplomat.com/2014/09/the-future-of-chinasconfucius-institutes/ (Letöltés: 2018. április 3.).

Wang, Gungwu (2000): The Chinese Overseas: From Earthbound China to the Quest for Autonomy. Harvard University Press, Cambridge.

Wei, Yingqi - Liu, Xiaohui - Lu, Jiangyong - Yang, Jingjing (2017): Chinese Migrants and Their Impact on Homeland Development. The World Econonomy, Vol. 40, No. 11, 2354-2377, http:// dx.doi.org/10.1111/twec.12475.

Wei, Yu - Sun, Zhaojun (2012): China: Building an Innovation Talent Program System and Facing Global Competition in a Knowledge Economy. The Academic Executive Brief, Vol. 2, No. 1, 4-9.

Xiang, Biao (2016): Emigration Trends and Policies in China. Movement of the Wealthy and Highly Skilled. Migration Policy Institute, New York.

Zagami, Leo Lyon (2016): Confessions of an Illuminati. The Time of Revelation and Tribulation Leading Up to 2020. CCC Publishing, San Francisco.

Zweig, David (2006): Learning to Compete: China's Efforts to Encourage a "Reverse Brain Drain." In: Kuptsch, Christiane - Pang, Eng Fong (eds.): Competing for Global Talent. International Labor Organization, Geneva. 